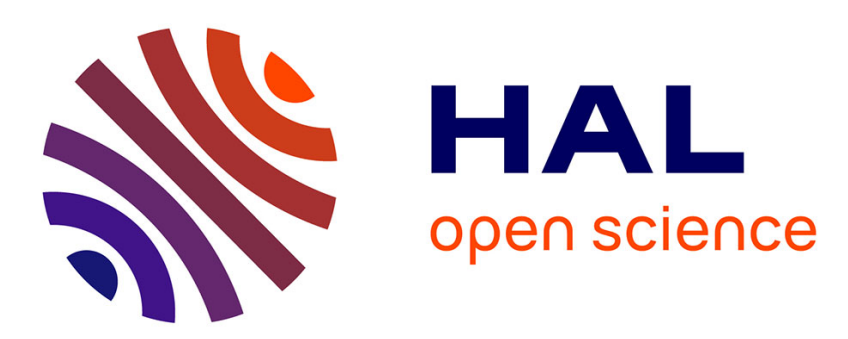

\title{
Building and interconnecting hydrogen networks : insights from the electricity and gas experience in Europe
}

\author{
Nuno Bento
}

\section{- To cite this version:}

Nuno Bento. Building and interconnecting hydrogen networks: insights from the electricity and gas experience in Europe. Energy Policy, 2008, 36 (8), pp.3009-3018. 10.1016/j.enpol.2008.04.007 . halshs-00266304

\section{HAL Id: halshs-00266304 \\ https://shs.hal.science/halshs-00266304}

Submitted on 21 Mar 2008

HAL is a multi-disciplinary open access archive for the deposit and dissemination of scientific research documents, whether they are published or not. The documents may come from teaching and research institutions in France or abroad, or from public or private research centers.
L'archive ouverte pluridisciplinaire HAL, est destinée au dépôt et à la diffusion de documents scientifiques de niveau recherche, publiés ou non, émanant des établissements d'enseignement et de recherche français ou étrangers, des laboratoires publics ou privés. 


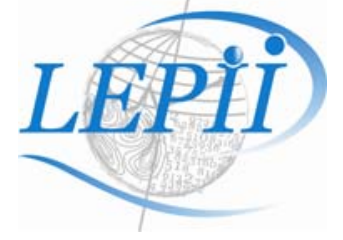

LABORATOIRE D'ECONOMIE DE LA PRODUCTION ET DE L'INTEGRATION INTERNATIONALE

UMR 5252 CNRS - UPMF

\section{CAHIER DE RECHERCHE \\ $N^{\circ} 8$}

\section{Building and interconnecting hydrogen networks :}

\section{Insights from the electricity and gas experience in Europe}

\section{Nuno Bento}

Mars 2008

\section{LEPII}





\title{
Building and interconnecting hydrogen networks:
}

\section{Insights from the electricity and gas experience in Europe}

\author{
Nuno BENTO \\ Ph.D. student \\ Laboratoire d'Economie de la Production et de l'Intégration - LEPII \\ University of Grenoble, Pierre Mendès France (France) \\ Mailing address: LEPII, UPMF - BP47 38040 GRENOBLE Cedex 9 France \\ Telephone: +33 (0)6 69297401 ; Fax: +33 (0)4 56528571 \\ Email: nunomcbento@hotmail.com
}

\begin{abstract}
This paper aims to investigate the transition to a new energy system based on hydrogen in the European liberalized framework. After analyzing the literature on the hydrogen infrastructure needs in Europe, we estimate the size and scope of the transition challenge. We take the theoretical framework of network economics to analyze early hydrogen infrastructure needs. Therefore, several concepts are applied to hydrogen economics such as demand club effects, scale economies on large infrastructures, scope economies, and positive socio-economical externalities. On the examples of the electricity and natural gas industry formation in Europe, we argue for public intervention in order to create conditions to reach more rapidly the critical size of the network and to prompt network externalities allowing for the market diffusion of and, thus, an effective transition to the new energy system.
\end{abstract}

Keywords: Network economics; infrastructure; hydrogen. 


\section{Introduction}

Hydrogen produced from renewable sources and used in fuel cells for different applications has the potential to revolutionize the future energy sector in a sustainable way. Today, $65 \%$ of global $\mathrm{CO} 2$ emissions come from energy uses, 21 $\%$ from transportation due to its dependence on fossil fuels. (WRI, 2006) Moreover, the emissions from transportation are expected to rise in the coming years, particularly in developing countries. The introduction of hydrogen and fuel cells, particularly in transportation, has the potential to curb radically greenhouse gas emissions, as well as to reduce the dependency on fossil fuels and improve air quality in the cities. (Barreto et al, 2003)

Even though hydrogen production is still more costly compared to other fuels particularly gasoline for transportation - recent technological advances in production and higher oil prices have improved hydrogen's economics. (NRC, 2004) Recently, many fuel cell producers have announced that the cost of fuel cells is approaching a competitive level, and demonstration projects are already on the road throughout the world.' (Ballard, 2007; IEA, 2004) Nevertheless, infrastructure availability is required before that hydrogen and fuel cell technology can be diffused into the market (especially for transportation). Without infrastructure there will be no demand for hydrogen and fuel cell technology, and automotive companies will be unwilling to supply fuel cell cars. On the other hand, without demand there will be no private agents interested in building up the infrastructure. This is the so-called "chicken-oregg" dilemma. (Sperling and Cannon, 2004)

The infrastructure problem is not new in the history of network industries. Several examples show that new infrastructures are built when required to overcome a national "strategic need." This was the case of interconnections for telecommunications, railways for trains, and even the electricity grid and natural gas pipelines in the energy sector. Each of these infrastructures has in common high initial costs with large uncertainties in demand uptake and the recovery period, which makes it unlikely that private agents will be interested in pursuing the investments at a national level. Hence, traditionally the State built networks using the argument of common interest. (Angelier, 2007; Bergougnoux, 2000)

In the newly liberalized European framework, financial burdens and international competition rules make it almost impossible for the government to build a new energy infrastructure on its own. At the same time, it is still unclear how the market will provide the investment needed to build the infrastructure and who will organize it. This paper aims to discuss the early hydrogen infrastructure transition in a market framework. More precisely, we focus on the following questions: How does the infrastructure evolve; what should be the role of public authorities leading up to the transition?

Numerous studies have focused in identifying the optimum decisions for hydrogen transitions (Plotkin, 2007), but very few have tackled explicitly industrial organization issues. We analyze hydrogen as a network industry. Our analyses cover the development of networks, in particular, in terms of industrial organization and 
demand behavior. The electricity and natural gas experience in Europe provides empirical ground for the discussion. Finally, we argue that public intervention is required in order to promote the new energy system.

\section{Hydrogen infrastructure challenges}

Hydrogen is the most plentiful gas in the universe but it only exists in nature associated with other elements from which it has to be extracted. So, like electricity, hydrogen is an energy carrier. It must be produced from a primary source and transmitted to the consumption place in order to deliver an energy service (stationary, mobile, portable) using fuel cells technology for higher efficiency. (IEA, 2005) An infrastructure for production and delivery is therefore required. In the case of mobile applications, hydrogen stations have to be provided also in a sufficient number, and must be appropriately distributed between premium and non-premium locations. (Melaina, 2003) In order to solve the "chicken-or-egg" problem, investors in fuel distribution, hydrogen production and vehicle manufacturing have to rely on each other's investments to start the system successfully. Furthermore, supply and demand should evolve together in order to reduce uncertainty and costs.

The issue in the transition period is to match an infrastructure sufficiently to enable the hydrogen consumption, of which evolution is very uncertain. In the beginning, hydrogen may use the existing energy infrastructure, particularly a natural gas one (transmission, feedstock supply, etc.). Moreover, current hydrogen producing plants could make available hydrogen surplus to the first consumption centers nearby (e.g. at refineries near the city limits). (Ogden, 1999b) Where new infrastructure must be fully constructed, first networks might be decentralized and hydrogen produced on site. (Ogden, 1999a) Although small scale hydrogen appliances can get the infrastructure started, investors might not be interested in investing in new equipment that becomes obsolete before being repaid. Incentives should therefore target these essential but unattractive investments. (Plotkin, 2007)

Meanwhile, demand expansion can justify building up a large production unit (scale economies and cheap feedstock prices) and establish the delivery infrastructure to bring the hydrogen to the consumption point. (Ogden, 1999a; Yang and Ogden, 2007) Regional specificities such as feedstock prices and demand density will determine the choice of the pathway, so the transition might look different from region to region. (Plotkin, 2007) The infrastructure (production, delivery and fuel stations) should be built incrementally in order to avoid investing in overcapacity which can increase the hydrogen price. (Melaina, 2003; Yang and Ogden, 2005) Even if there is no sufficient demand in the medium term, the economics of large hydrogen plants can still be improved if there are other uses for the hydrogen such as ammonia manufacturing or market for heat and power. (Ogden, 1999a)

In its vision for hydrogen in Europe, the High Level Group (HLG, 2003) considers the following market penetration in the transport sector: $5 \%$ of all new cars by 2020 (or 2 $\%$ of the fleet by that time); $25 \%$ by 2030 (or $15 \%$ of the fleet); and $35 \%$ by 2040 (or $32 \%$ of the fleet). Many studies have followed trying to estimate infrastructure costs and discuss the best strategies to get there from here. 
The "HyWays" project is the largest analysis of the hydrogen infrastructure done for Europe. (Stiller et al., 2007) In 2007, the consortium presented a roadmap for the hydrogen introduction in Europe. The analysis takes into account, firstly, the profile of each member state in terms of infrastructure, domestic resources, socio-economic factors, etc.; and secondly, the objectives of the European policy particularly in terms of hydrogen penetration, $\mathrm{CO} 2$ emissions reduction, diversification of the energy mix, and incorporation of renewable resources. The total investment cost at the end of Phase III (2027) was estimated to 60 billion euros. It was also reported that hydrogen has the potential to halve $\mathrm{CO} 2$ emissions and reduce by $40 \%$ oil consumption in transportation in Europe by 2050.

Other studies were performed in order to estimate the cost of the hydrogen infrastructure for Europe. The main results and assumptions are shown in table 1. The analyses confirm the need for large investments.

Table 1 Synthesis of results of hydrogen infrastructure studies for Europe

\begin{tabular}{|c|c|c|c|c|c|}
\hline Study & Countries & Scope & Demand & $\begin{array}{c}\text { Key scenarios } \\
\text { drivers }\end{array}$ & $\begin{array}{c}\text { Cumulated } \\
\text { Investments }\end{array}$ \\
\hline $\begin{array}{l}\text { HyWays } \\
(2007)\end{array}$ & $\begin{array}{l}10 \text { countries } \\
\text { (Finland, } \\
\text { France, } \\
\text { Germany, } \\
\text { Greece, } \\
\text { Italy, } \\
\text { Netherlands, } \\
\text { Norway, } \\
\text { Poland, } \\
\text { Spain, } \\
\text { UK) }\end{array}$ & Transport & $\begin{array}{l}\text { HLG (2003) } \\
500,000 \text { cars in } \\
2027 \\
\text { (17,000 fueling } \\
\text { stations - } 85 \% \text { of } \\
\text { the population } \\
\text { coverage) }\end{array}$ & $\begin{array}{l}\text { population coverage ; } \\
\text { "policy support", } \\
\text { "technological } \\
\text { learning" ; type of } \\
\text { production (forecourt } \\
\text { and centralized) \& } \\
\text { delivery (liquid, } \\
\text { gaseous, etc.) }\end{array}$ & $60 \mathrm{bn} €(2027)$ \\
\hline $\begin{array}{l}\text { Tzimas et } \\
\text { al. (2006) }\end{array}$ & $\begin{array}{l}\text { European } \\
\text { Union - } 25 \\
\text { countries } \\
(\text { EU25) }\end{array}$ & $\begin{array}{l}\text { Transport, } \\
\text { stationary }\end{array}$ & HLG (2003) & $\%$ market penetration & $\begin{array}{l}700- \\
2,200 \text { bn } € \\
\text { (2050, delivery } \\
\text { infrastructure) }\end{array}$ \\
\hline $\begin{array}{l}\text { Wietschel } \\
\text { et al. } \\
(2006)\end{array}$ & EU25 & $\begin{array}{l}\text { Transport, } \\
\text { stationary }\end{array}$ & $\begin{array}{l}\text { Sc.A } \\
\text { (high penetration) } \\
20 \% \\
\text { Sc.B } \\
\text { (low penetration) } \\
5 \%\end{array}$ & $\begin{array}{l}\text { \% substitution of fossil } \\
\text { fuels by hydrogen; } \\
\text { share of renewable in } \\
\text { the hydrogen } \\
\text { production }\end{array}$ & $\begin{array}{l}60 \mathrm{bn} € \\
\text { (2030, sc.A, } \\
\text { centralized } \\
\text { prod. with } \\
\text { carbon capture } \\
\text { and storage) }\end{array}$ \\
\hline $\begin{array}{l}\text { E4Tech } \\
\text { (2005) }\end{array}$ & $\begin{array}{l}\text { Austria, } \\
\text { Belgium, } \\
\text { Czech } \\
\text { Republic, } \\
\text { Denmark, } \\
\text { Finland, } \\
\text { France, } \\
\text { Germany, } \\
\text { Greece, } \\
\text { Hungary, } \\
\text { Ireland, } \\
\text { Italy, } \\
\text { Netherlands, } \\
\text { Portugal, } \\
\text { Poland, } \\
\text { Sweden, } \\
\text { Spain, } \\
\text { Switzerland, } \\
\text { UK }\end{array}$ & Transport & $\begin{array}{l}\text { « High » } \\
\text { 40million vehicles } \\
(2030) \\
\text { "low" } \\
\text { 20million vehicles } \\
(2030)\end{array}$ & $\begin{array}{l}\text { demand ; type of } \\
\text { production; } \\
\text { « population density »; } \\
\text { « automotive (tradition) } \\
\text { areas» }\end{array}$ & $\begin{array}{l}\text { (2030; high } \\
\text { uptake; } \\
\text { « automotive »; } \\
\text { centralized } \\
\text { prod.) } \\
\mathrm{H}^{2} \text { fueling } \\
\text { stations : 6bn € } \\
\text { Production \& } \\
\text { distribution : } \\
\text { 11bn M€ }\end{array}$ \\
\hline
\end{tabular}


In addition to the infrastructure challenge, technology costs must be substantially reduced in the coming years so as to make hydrogen competitive with energy substitutes. This is the conclusion of the hydrogen prospective study, WETO-H2 (2007), which in the reference scenario (maintaining of the current trends) forecasts that hydrogen will not exceed $2 \%$ of global energy consumption in 2050 (3\% in Europe). In the "hydrogen" scenario, characterized by carbon constraints and very optimistic assumptions concerning costs reductions in fuel cells, the proportion of hydrogen in the final energy consumption will not exceed $13 \%$ and $7 \%$, respectively.

Hydrogen can be produced from renewable electricity and become virtually "carbon free". Nevertheless, the low renewable electricity available in the medium term would save more greenhouse gas emissions by replacing old cold-fired power plants than by producing hydrogen for transportation. (Plotkin, 2007) Hence, it is likely that hydrogen will be first produced from fossil fuels until renewable technologies become more competitive, which is not expected to happen until 2030. (HLG, 2003) The transition for the hydrogen economy is therefore dependent on the progress done in both the carbon capture and storage technologies, and in the renewable technologies.

In conclusion, entry and penetration of hydrogen into the market depends critically on the existence of the infrastructure. The necessary investments are very expensive especially as uncertainties persist in technology and on demand behavior. In this too risky context, it seems unlikely that private companies (oil, gas, electricians, automakers, industrial gas companies, etc.) will take over the investments alone, without any public support.

\section{The economics of network industries}

\subsection{Network externalities}

A Network is a spatial interconnection of activities and equipment technically compatible. (Economides, 1995) Network industries are characterized by the presence of network externalities. These external effects can be generated directly by increasing demand (the club effects), or indirectly by declining commodity prices through scale economies, or improving quality by the diversification of the service (scope economies). (Economides, 1995) Moreover, the development of networks leads to positive effects on the overall economy. As the complete amount of costs and benefits is not fully taken into account for the market equilibrium, the private equilibrium does not coincide with the social optimum. (Coase, 1960) Public intervention is therefore necessary.

\subsubsection{Club effects}

The definition of club effects was first established by Buchanan (1965) for those goods and services by which consumption utility depends on the number of users. In the case of club goods, individuals increase their utility as the number of adherents is growing (up to the saturation point beyond which club effects are not acting anymore). Katz and Shapiro (1985) noted that user's satisfaction increases with the expected future size of the network. So, an expected bigger network provides a higher satisfaction for its users. 
In particular, club effects constrain the dynamics of the network development. Network externalities are the source for increasing returns in the adoption, which means that the spread of network goods does not follow a linear path, but rather an S-curve (Figure 1). Multiple stable equilibriums are therefore possible, depending on whether the critical mass is attained or not. Hence, club effects can explain the rapid diffusion of the network as well as its failure when it can not reach the critical mass and spread out from there. (Arthur, 1989; David, 1985)

Figure 1 Typical network diffusion with club effects

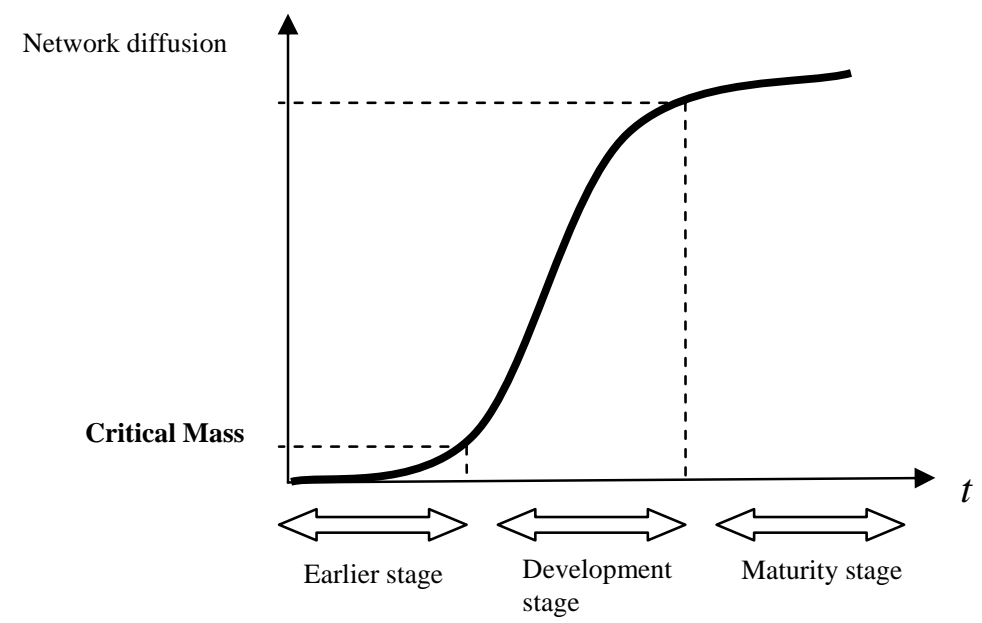

The spread of a network usually follows a succession of three different stages: (i) a slow start period until a minimum level is reached (critical mass); (ii) once the critical mass is reached, the "installed basis" membership increases the attractiveness of the network. The arrival of new users improves the network attractiveness contributing to more adhesions, in a feedback effect, conducing to a fast diffusion rate of the network; (iii) in the third stage, the potential for growth is exhausted, the network reaches the saturation point and the industry maturity is attained. (Shapiro and Varian, 1998)

Diffusion and survival of the network depends on whether the critical mass is reached or not. So, promoters of a new network should aim to reach the critical level as a minimum target, which must be achieved in one jump step. Otherwise, the only stable equilibrium will be the absence of the network. (Curien, 2000; Economides, 1994)

\subsubsection{The effects of scale and scope}

The high capital intensity of network industry is a source of many effects at the operational level that can be fully exploited by chain integration. We will consider two of those effects: scale economies and scope economies. Scale economies exist when the average production costs decrease with the scale of production or the production volumes. (Braeutigam, 1989)

This feature is present in network industries such as telecommunications, electricity and natural gas. The development of networks often requires the establishment of a heavy technical structure requiring high initial investments that can not be easily deployed in another activity (sunk cost). The initial fixed costs are a source of increasing revenues elevating the scale of the efficient production and dominating the 
final price. (Curien, 2000) Furthermore, the marginal cost of providing services is often constant or even decreasing for the relevant economic quantities. The bulk of the network being established, the adhesion of a new membership contributes to expand club effects and sharing costs more than increasing exploration costs.

Scope economies are achieved by joint production of different goods or services, within the same company, through various production processes sharing a common input. In the presence of scope economies, producing $n$ different goods or services separately becomes more expensive than producing them together given synergies in the production. (Baumol et al., 1982)

Network industries are heavily influenced by scope economies. A large network can attract several related activities, therefore reinforcing its value. A recent example is the emergence of multi-utility companies proposing a multitude of services beyond their core business (telephone, internet, multi-energy contracts, etc.). This allows the utility to optimize their infrastructure, as well as to expand the range of services offered to the clients.

\subsubsection{The dynamic effects on the economy}

Endogenous growth theories defend that investing in public infrastructures such as transport infrastructure or energy networks, generates economic positive externalities. (Barro, 1990) Investment in infrastructure affects directly the product by increasing total investments, particularly because public investment can be seen as an additional production factor in the economy. On the other hand, new infrastructure generates positive externalities in terms of aggregate output of the economy. It allows for a more efficient functioning of markets, which benefits all businesses and citizens. Finally, investing in new infrastructure entails indirect effects for the economy through the increase of factors productivity (capital and labor). Even though public expenses in infrastructure can provoke a crowding out effect by decreasing demand of private factors, this also contributes to increasing their productivity. Hence, a reduction in costs and an increase in the overall production would be expected.

\subsection{Natural monopoly}

An industry operates in a natural monopoly situation if a single company produces with lower costs than a combination of smaller companies. (Braeutigam, 1989; Lévêque, 2004) In the case of the electric power industry, for example, the duplication of the transmission wires to serve the same consumer is not efficient. In this case, competition does not lead to a cost-effective solution and results rather in perverse effects in terms of price volatility. Therefore, a public intervention is necessary.

The natural monopoly situation may have different sources, most of them related to technological externalities. It may be associated to strong scale economies (due to the importance of fixed costs, average costs decrease following the increase of the production); scope economies (related to variable costs and economies of joint production); and network economies (related to interconnection and system control); or even a combination of all these effects. (Baumol et al., 1982 ; Curien, 2000) 
Efficiency can be severely affected in the case of stable natural monopoly (decreasing costs for all relevant quantities). Even though monopoly can still produce more efficiently than in an atomized market, it will maximize profits by pricing higher and offering fewer quantities as compared to the collective optimum situation. (Lévêque, 2004) In this context, the public authority must intervene in order to increase the social surplus. It can take one of the two modalities: regulating the private monopoly or replacing it by a public monopoly. (Angelier, 2007)

\subsection{The problem of building and expanding private networks}

An important characteristic of network industries is ubiquity. (Angelier, 2007) As for hydrogen, consumers will purchase a stationary appliance such as a small fuel cell co-generating power and heat (CHP), if there is an infrastructure, sufficiently large, capable of bringing hydrogen to their front door. On the other hand, they might be interested in purchasing a hydrogen car when they can easily find a hydrogen station in town as well as on the way to the beach during their long trips.

In search of a maximization behavior, private societies are motivated to focus only in mass consumption areas. Besides, expanding their networks might not be profitable, and interconnections with neighbor networks can increase the competition which ultimately is not of interest. In our example, setting hydrogen stations in rural areas (non premium locations) is a determinant for hydrogen attractiveness, but investors may not be interested in it, at least, in the beginning of the transition.

When networks are built by private companies, the problem may not be to start local networks in highly profitable areas, but it is rather the coordination of the investments and the interconnection of the networks. Noam (1992) noticed a similar problem in the history of the telephone networks development.

Figure 2 Stages in the network expansion

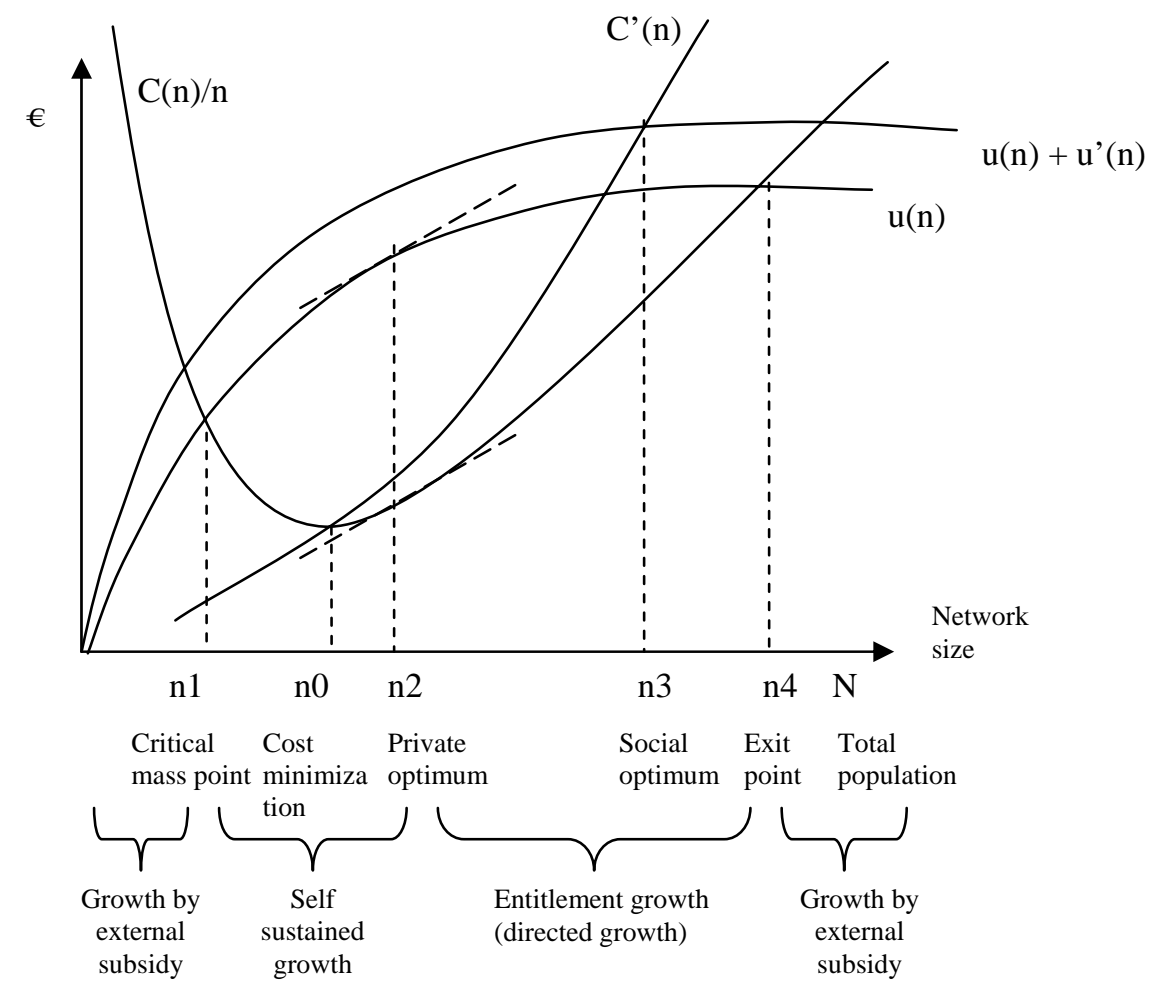


Source: Noam, 1992.

According to Noam's model, the initial cost of the network is too heavy to be shared among users. So, the network can not start without an external support. After reaching critical mass size (n1), it enters a period of self sustained growth. It means that private societies find it economical to expand their networks to new entrants mainly because of the scale economies and club effects. They will keep expanding the network until reaching the size that maximizes their profits $(n 2)$, where the difference between the private utility $[u(n)]$ and the average cost curve $[c(n) / n]$ is maximal. After the private optimum, the private marginal benefits of expanding the network are inferior to the marginal expansion costs (saturation, complexity costs, etc.), and therefore privates are no more interested in expanding the network. However, in a social perspective, the network should be expanded, since the collective utility from the last member arrived--measured by the addition of its utility and the utility increment for the other members of the network [u(n)+u'(n)]--is still above the marginal cost. There is a tension between the interest of public authorities in promoting the network development and the interest of private societies installing it. Considering the public authority is successful in convincing privates in expanding their network, and it is interested in universal access, later on companies are not willing to develop the network after the point where they start making losses ( $n 4$ where the average cost is not fully covered by the price). Any expansion from that point on can not be done without an external subsidy like in the beginning of the network.

In conclusion, firstly, the network expands by economical and technical reasons but later the expansion becomes a matter of political choice. Moreover, it is difficult that national networks kick off and reach the critical mass without any public support.

\section{The historical development of the electricity and gas networks in Europe}

The following sections analyze the evolution of the electricity and natural gas in Europe. This analysis illustrates the effects of the network externalities on the development of those industries, as well as the role of public authorities and private agents on the process. Moreover, hydrogen introduction might have multiple interactions with both industries in the future, particularly with natural gas.

\subsection{The electricity industry}

The electricity industry emergence in the four main countries of Western Europe (Germany, France, Italy and Great Britain) began in the early 1880s. The period of major diffusion occurred between 1950 and 1980. The evolution of the electricity industry process can be decomposed in four distinct stages: (i) the emergence of the industry, from the 1880s until the beginning of World War I; (ii) enlarging markets and the beginning of the electricity policy in the period between the two World wars; (iv) the operational harmonization and growth of domestic industries after World War II; and (v) the arrival to maturity and deregulation after 1980. (See Graph 1) 
Graph 1 The evolution of the electrical industry in Europe between 1885 and 2005 (TWh)

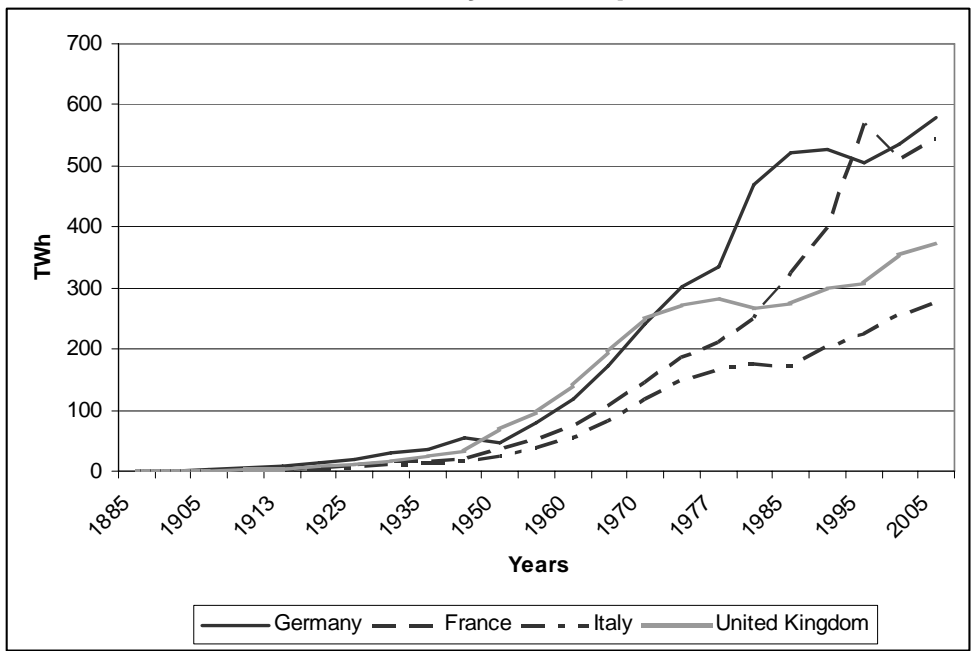

Source : EIA, 2007 (AER 2006) ; Angelier and Lalanne, 1979.

From the emergence of electricity in the Western European countries until the "takeoff," more than 60 years passed. Since the beginning, the evolution of the electric power industry has experienced different rhythms, paths and performances depending on the country. There were three main factors influencing the development of the national electricity industries: physic-economic country conditions; the origins of the capital; and the implication of public authorities in the development of the industry. (Angelier and Lalanne, 1979; Lanthier, 2006)

\section{The emergence of the electricity industry: 1880-1913}

Initially, the electric power industry was based on thermal and hydropower production. In the early years, the purpose of electricity was to convert thermal energy into a form of energy more suitable for certain energy needs such as lighting. Moreover, governments aimed to replace imported energy by maximizing national resources such as hydro. Until World War I, the main markets for electricity were lighting and traction.

During the first stage, the power industry remains generally confined to major urban centers and industrial highly consuming areas, where consumption is spread over the whole day. The industry structure varies from one country to another: concentrated in Germany and Italy; atomized in the United Kingdom; and highly concentrated in major consumer centers in France. (Bergougnoux, 2000; Stoffaës, 1994) The German electric industry is the most developed as compared to other electricity industries in terms of electricity production, costs and electricity prices, geographically widespread network and diversification of the production mix. (Angelier and Lalanne, 1979)

\section{The enlargement period: 1918-1938}

The second stage corresponds to the period between the two World wars. During this stage, the electricity industry had realized substantial progress in transportation and production. From now on, electricity can be transported over long distances and in more economical conditions. This allowed for a geographic expansion of local networks into the regional framework, and later on, in a national framework with the 
interconnection of various regional electricity grids. The expansion of the market is also associated to the growth of the production scale and the introduction of new power generation technologies (e.g. turbine). It improves the efficiency in the use of the fuel in the generating station, which allowed for substantial price reductions at the consumption (e.g. constant prices were divided by a factor of 5 in Paris between 1914 and 1939). Therefore electricity becomes accessible to more and more persons and can finally progress over the niche markets. (Stoffaës, 1994)

During this period, electricity energy integrates the country energy consumption and contributes to economic competitiveness and growth. Firstly, electric power was mainly used for industrial needs. Industrial demand accounts for more than two thirds of the electricity consumption (except in the United Kingdom where it provided only $50 \%$ ) between the World wars. (Angelier et Lalanne, 1979) In fact, the growth in electricity industries was linked to the electric motor ability to replace the steam engine in industrial use.

\section{The growth of the national electricity industries: 1945 - 1980}

After World War II, the demand for electricity had progressed very fast. This progression was mainly driven by the demand of the residential and service sector. The share of the residential and service sector in the total demand rose from about one fifth in 1950 to one half in 1977. (EIA, 2007) The structural change in demand is due to the extension of the distribution networks covering a larger portion of the population, and to the increasing importance of the services sector in the western economies.

In the face of a rapid growing demand and fragmented electricity networks, national organizations under increasing control of the State were created in Europe aiming to harmonize the operations and diffuse widely electrification. Different factors explain the decision to nationalize the industry: the strategic importance of the electric power industry in a framework of reconstructing economies needing more energy; technical change in production and transmission turned the electricity industry into a natural monopoly; the role of the electricity industry as an instrument of regulation and public intervention in the economy. (Angelier et Lalanne, 1979; Stoffaës, 1994)

The electricity industry was nationalized in France and in the United Kingdom. In Italy, the State "nationalizes" the industry through a process of gradual redemption of financial investments in electricity companies. By contrast, in the former West Germany, the central government sold a part of its stake in public electric holdings to private companies, particularly to financial groups.

\section{The arrival to maturity and the deregulation period after the $1980 \mathrm{~s}$}

The two oil shocks in 1973 and 1978 and the subsequent stagflation crises in the western economies are in the basis of the strong deceleration in the power industry after the 1970s and 1980s. On the one hand, the fuel prices increase as well as the inflation raised the production and the investment costs. On the other hand, demand growth globally slows down after the 1980s (e.g. in France, demand growth rates fell from more than $7 \%$ to $4 \%$ respectively in the period before and after 1881). (EIA, 2007) Moreover, there were new plants entering in production by that time, which resulted in a global overcapacity situation (e.g. nuclear overcapacity in France). 
The electricity industry was first deregulated in the United States, where private companies are historically responsible of three quarters of the electricity produced and sold. (Stoffaës, 1994) In Europe, deregulation starts in Great Britain in 1991 with the restructuring followed by privatization of the electric integrated firms. The movement continued in the European continent in the framework of the creation of an internal market for energy. The process was mainly defined in two directives (in 1996 and in 2003) which lay down the liberalization principles: the unbundling of the concurrence activities in production and retailing from the essential facility considered as a natural monopoly; third party access (TPA) to the networks; the creation of a regulator to survey the concurrence and the natural monopoly activity; and progressively opening the market starting with bigger consumers. The rhythm of liberalization is not homogenous among countries, alternating between competitive markets in Great Britain and Italy, and still highly concentrated in France and in Germany. (Finon and Midttun, 2004)

In conclusion, the electrification process was globally influenced by the intervention of public authorities. Depending on the network evolution stage (local, regional, national), a different hierarchical level of public administration intervenes in the process (municipalities, regions, State.) At each stage of the process, especially in countries where the private sector was important, there were tensions for the investment in the network: between the municipality and the local utility, at first; or the State and the multinational group, later. (Lanthier, 2006) The result was the fragmentation of the electricity networks with different technical standards. After World War II, in the context of rapid increase in demand and a fragmentized network, the State integrated the entire chain in order to avoid growth bottlenecks (e.g. standardization of the technology), to maximize the benefits from club effects and scope economies, and to overcome the critical size more rapidly. This coincides with the strongest growth rates that electrical industry had ever known. Technical innovations in production and transmission were critical in the development of the industry at a national level. More recently, demand growth deceleration and network established, the disadvantages of vertical integration became clearer (bureaucratic organization inefficiencies or 'X-inefficiencies,' new technologies in production with low scale economies, etc.). The conditions were created for opening the industry to competition.

Table 2 Summary of the historical development of the electric power industry in Europe since 1880

\begin{tabular}{|c|c|c|c|c|c|}
\hline & $\begin{array}{c}\text { Principal } \\
\text { usage }\end{array}$ & $\begin{array}{c}\text { Utilization } \\
\text { technologies }\end{array}$ & Actors & $\begin{array}{c}\text { Production } \\
\text { technologies }\end{array}$ & $\begin{array}{c}\text { Network } \\
\text { evolution }\end{array}$ \\
\hline $\begin{array}{l}\text { The emergence } \\
\text { stage: } 1880- \\
1913 \\
\text { Infancy }\end{array}$ & $\begin{array}{c}\text { Lighting } \\
\text { Public } \\
\text { transportation }\end{array}$ & $\begin{array}{l}\text { Electric bulb } \\
\text { Electric motor }\end{array}$ & $\begin{array}{c}\text { States } \\
\text { Communes } \\
\text { Electromechanic } \\
\text { companies } \\
\text { Industry } \\
\text { Banks }\end{array}$ & $\begin{array}{c}\text { Thermal } \\
\text { (coal) } \\
\text { Hydropower }\end{array}$ & $\begin{array}{l}\text { Small urbain } \\
\text { networks }\end{array}$ \\
\hline $\begin{array}{l}\text { The } \\
\text { enlargement } \\
\text { stage : 1914- } \\
1938 \\
\text { «take -off » }\end{array}$ & Industry & $\begin{array}{l}\text { Electric motor } \\
\text { Electric bulb }\end{array}$ & $\begin{array}{c}\text { States } \\
\text { Communes } \\
\text { Private societies }\end{array}$ & $\begin{array}{c}\text { Thermal } \\
\text { Hydropower } \\
\text { (large scale) }\end{array}$ & $\begin{array}{c}\text { Network } \\
\text { interconnection } \\
\text { and regional } \\
\text { networks }\end{array}$ \\
\hline $\begin{array}{l}\text { The growth } \\
\text { stage : 1945- } \\
1977 \\
\text { Diffusion }\end{array}$ & $\begin{array}{l}\text { Domestic } \\
\text { Services }\end{array}$ & $\begin{array}{l}\text { Household } \\
\text { appliances } \\
\text { Electronics }\end{array}$ & $\begin{array}{c}\text { States } \\
\text { Communes } \\
\text { (public and private } \\
\text { stakeholders in } \\
\text { Germany) }\end{array}$ & $\begin{array}{c}\text { Thermal } \\
\text { Hydropower } \\
\text { Nuclear }\end{array}$ & $\begin{array}{c}\text { National } \\
\text { transport } \\
\text { network and } \\
\text { large } \\
\text { distribution } \\
\text { network }\end{array}$ \\
\hline
\end{tabular}




\begin{tabular}{|c|c|c|c|c|c|}
\hline $\begin{array}{l}\text { The } \\
\text { deregulation } \\
\text { stage: since } \\
1980 \\
\text { Maturity }\end{array}$ & $\begin{array}{l}\text { Domestic } \\
\text { Services }\end{array}$ & $\begin{array}{l}\text { Household } \\
\text { appliances } \\
\text { Electronics }\end{array}$ & $\begin{array}{l}\text { Private societies } \\
\text { Public - private } \\
\text { societies }\end{array}$ & $\begin{array}{l}\text { Thermal } \\
\text { (combined } \\
\text { cycles) } \\
\text { Hydropower } \\
\text { Nuclear } \\
\text { Renewable }\end{array}$ & $\begin{array}{c}\text { International } \\
\text { interconnection } \\
\text { (continental } \\
\text { networks) }\end{array}$ \\
\hline
\end{tabular}

\subsection{The natural gas industry}

The natural gas industry has its origin in the town that gas was developed during the nineteenth century and the first half of the twentieth century. The gas mains for the town were firstly built in the major cities and then in smaller towns. Public and private lighting became the first major outlets for the gas. In the late nineteenth century, this market was already threatened by the introduction of electric lighting. The competition with electricity continued until the gas industry found its next impetus for growth in calorific usage. In the 1920s, technological progress and excess production contributed to concentrate the production in more efficient large-sized plants, putting basis for the creation of the first transport networks at the regional level. (Paquier and Williot, 2005) Nonetheless, after the 1930s, production modernization was not sufficient to prevent the decline of manufacturing gas due to coal scarcity and the competition from electricity and petroleum. (Odell, 2001)

\section{The natural gas emergence in the 1950s and 1960s}

Natural gas appears in a difficult context for the gas industry. Cleaner and having a better gross calorific value, natural gas was also a cheap energy grace to the major deposit discoveries of the 1950s and the 1960s across Europe. "Moreover, in the period after World War II, the European economic reconstruction required significant amounts of energy, which explains the authorities' willingness to promote the new energy. (Angelier, 1994; Smit, 2006) The first transmission and distribution networks of natural gas were built in Europe by that time. The transportation networks kicked off linking the producing areas with the main consumption areas nearby. In large cities, the introduction of natural gas was facilitated by the town gas infrastructure already in place. (Angelier, 1994; Paquier and Williot, 2005)

The resurgence of the gas industry is accompanied by an institutional change intended to facilitate the transition. The major national firms were created after World War II. In 1953, the Italian government created the national oil and gas company ENI (Ente Nazionale Idrocarburi) which reorganizes the sector by incorporating the firm in charge of the transportation and the distribution of natural gas, SNAM (Società Metanodotti Nazionale). In France, the nationalization law of electricity and gas 1946 set up a national company for electricity (Electricité de France - EDF) and other for gas (Gaz de France - GDF). GDF results from the merger of the other gas companies, excluding mixed-capital and municipal companies. In Great Britain, the Gas Act 1948 nationalized the entire industry of town gas and divided it into a dozen area boards under coordination of the Gas Council. In 1973, the area boards and the Gas Council merged into the public company "British Gas Company." (The company was privatized and unbundled after 1986.) In 1963, the Dutch State in partnership with Exxon and Shell created Gasunie, the company responsible for production and transportation of natural gas from the Groningen deposit. In the former Federal 
Republic of Germany (FRG), the natural gas industry was developed in a more regional basis. The industry was composed by transporter/importer companies (Ruhrgas on the lead), regional transporters and local utilities (Stadtwerke), most of them public owned. The geographical demarcation contracts between transporters, as well as the concession contracts assigned to local utilities, created territorial monopolies preventing concurrence between firms. (Teece, 1990)

Almost everywhere in Europe, public companies convert and modernize the old town gas network, interconnect regional networks and lay down transport networks for natural gas.

\section{The natural gas diffusion after the 1960s}

After the 1960s, natural gas has progressed very rapidly in the energy balances of the Western economies thanks to deposit discoveries and technical innovations in the pipelines construction (high pressure allowing for great distances transport). (See graph 2)

\section{Graph 2 Natural gas penetration in national primary energy mix}

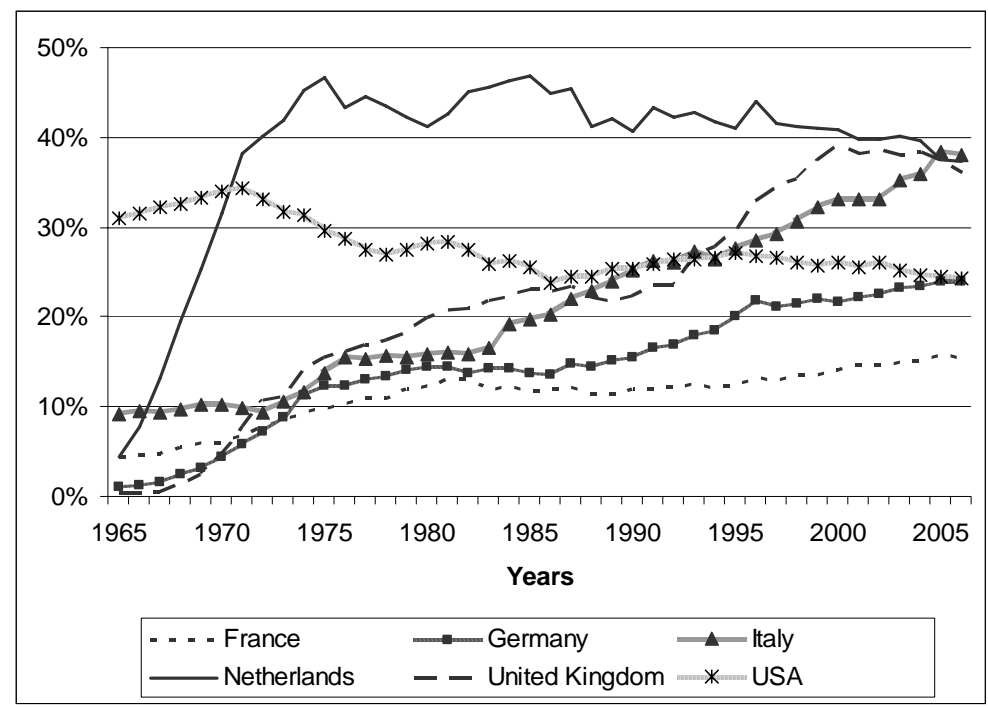

Author's calculations from BP (2007).

In the early 1960s, the natural gas industry is taking off in Europe while in North America it is already a consolidated industry, enjoying one third of the national energy mix. In Europe, natural gas has the greatest weight, in Italy meeting about $10 \%$ of total energy consumption. France and the Netherlands stand behind Italy in terms of penetration in the energy balance, while it is almost absent in the United Kingdom and Germany.

Natural gas progressed very fast in the energy balances reaching $10 \%$ in 10 15 years on average. This rapid penetration was possible grace to the quick network construction. Table 3 shows the rhythm of the transport pipeline construction in four European countries, between 1970 and 1990. 
Table 3 Length of high-pressure pipeline network in Europe $(1,000 \mathrm{~km})$

\begin{tabular}{|l|c|c|c|c|c|}
\hline Country/year & $\mathbf{1 9 7 0}$ & $\mathbf{1 9 7 5}$ & $\mathbf{1 9 8 0}$ & $\mathbf{1 9 9 0}$ & $\mathbf{1 9 9 0 / 1 9 7 0}$ \\
\hline France & 15.8 & 18.4 & 23.6 & 30.1 & $\mathbf{1 . 9 1}$ \\
\hline Germany & 32.3 & 38.8 & 51.7 & 77.2 & $\mathbf{2 . 3 9}$ \\
\hline Italy & 8.5 & 10.7 & 15.1 & 23.1 & $\mathbf{2 . 7 2}$ \\
\hline Netherlands & 8.4 & 8.8 & 9.5 & 10.5 & $\mathbf{1 . 2 5}$ \\
\hline United Kingdom & 2.5 & 5.7 & 12.1 & 13.5 & $\mathbf{5 . 4 0}$ \\
\hline
\end{tabular}

Source: Estrada et al., 1995, p.321.

The United Kingdom multiplied its transmission network length by a factor of 5 during the period 1970-1990, following the diffusion of the natural gas in the market as well as the rhythm of putting into production the wells discovered in the British shelf. In Germany and in Italy, the length of the transmission pipelines also progressed very fast during the period. In the case of the Netherlands, the main infrastructure was built right after the Groningen discovery, in the 1960s, and natural gas assumed a major role in the energy mix henceforth. (Smit, 2006) In France, the construction rhythm of the transmission pipelines was more stable compared to other countries, reflecting the smooth progression of natural gas in the market. This is due primarily to the political engagement for nuclear in response to the oil crisis of the 1970s.

Compared to the United States, the gas industry is historically more concentrated in Europe. In the United States, transport is traditionally organized within private monopolies under the control of the federal regulator, while distribution is generally a matter of municipal or private local distribution companies under the control of the State Public Utility Commission. (Angelier, 1994) After the end of the 1970s, in the context of a "gas bubble," prices and tariffs were deregulated and the industry was restructured, separating the transport and the trading business. Therefore the networks were opened to producers and consumers, which had lead to the development of spot markets at gas hubs. (MacAvoy, 2001 ; Teece, 1990)

In Europe, companies had soon found that domestic reserves were not enough to supply the growing demand, so it was necessary to build a costly infrastructure to bring gas from far locations. Those infrastructures were constructed between national gas producers-exporters and international consortiums formed by gas companies from European importing countries. iii They were accompanied by the signature of long-term import contracts (20-25 years) with indexation clauses to the crude oil price (to insure the competitiveness of the natural gas at the consumption) and obligation of consumption (clause "take or pay"). These clauses were meant to share the "price risk" and the "market risk" between the counterparts. This institutional architecture (oligopoly in production and importing activities; and closed national markets) enabled the development of stable and mature European supplies. (Odell, 2001)

\section{The changing institutional framework after the 1990s}

The integrated structures have been challenged by the liberalization organized around two gas directives (Directive 98/30 of June 1998 and Directive 2003/55 of June 2003). They have introduced the principles of the unbundling of the vertically integrated companies between the competitive activities (in the production and retail) and the essential facility (transport), the third-party access to networks and the regulation of the activities remaining in monopoly. Even though some progress has 
been recorded (i.e. the time and scope of the contracts has been reduced), markets are still far from a complete concurrence situation. Where former gas incumbents were not unbundled, they are still dominating the market (e.g. France, Italy, Germany). (Finon and Midttun, 2004) Furthermore, as domestic resources are becoming scarcer in the context of a rising demand, the European gas market has to rely in more foreign gas which raises security of supply concerns, as well as the need of investing in new infrastructure to bring that gas (which is an important issue to be solved by public and private agents in the coming years.)

In conclusion, the gas experience in Europe is an illustration of the market weakness to manage the development of national networks. While the town gas industry was generally limited to a local level, the natural gas industry was developed at a national (and international) scale. In the early years, the States integrated the natural gas business in national companies in order to generate scale, scope and system economies, and therefore developing this industry quickly. In a competitive environment, such as in the case of the town gas, the search for a solvent demand in order to maximize the return on investments is often done without taking into account network externalities and long-term investment needs. (Angelier, 2007, p.65; Noam, 1992) This behavior limits the network development at the national level. Public intervention is then necessary to enlarge the networks, particularly to interconnect fragmented networks creating a large national one.

\section{Prospects for the hydrogen transition based on the electricity and gas experience}

Both electricity and natural gas reached a critical mass after which their market shares started to increase rapidly grace to network externalities. The natural gas diffusion benefited from the availability of the town gas infrastructure in the cities, and from local discoveries after the 1950s. Electricity developed quickly due to the high voltage transmission and the turbine introduction after the 1920s. In both cases, they started as decentralized networks that were interconnected to form regional networks, and then national systems. Electricity took about 60 years before reaching the critical mass and diffusing widely. Town gas failed to become a national energy, and it was replaced by natural gas which needed just a few decades to be diffused in the major European countries.

The diffusion of electricity benefitted from the wide recognition of its technological superiority in lighting and other household appliances. The superiority of the electric motor as compared to steam engine was decisive for increasing the electric consumption in the industry sector, which was the main driver of the electricity progression during the first half of the XXth century. Technical progresses in production and in transmission made electricity cheaper and more available, creating therefore the conditions for the network development at the national level. Technical progress was also important in the case of natural gas. In fact, without progress in the steel industry--particularly in pipeline construction--the network widespread would not be possible.

In both cases the government backed the establishment of the supporting infrastructure. National organizations under public control were created in the 
electricity industry charged to the operational harmonization and to growing the network coverage. In the case of natural gas, national companies were formed in order to organize the local production and to build up the infrastructures needed to serve users. (See Table 4 for a synthesis) It is true that natural gas benefited from a favorable circumstance (local discoveries, growing energy demand, the old town gas infrastructure, etc.). Nevertheless, we can raise the following question: was the diffusion of natural gas in Europe relatively quicker because of the early State intervention?

The development of energy networks requires huge investments with long delays of recuperation of the capital before they can reach the critical mass and diffuse by the mean of network externalities and scale economies. In this context, it is unlikely that private companies will invest alone in infrastructure needed to widespread the hydrogen use at a national level. The intervention of the State is therefore necessary to support the early infrastructure deployment.

Table 4 Synthesis of infrastructure transition needs

\begin{tabular}{|c|c|c|c|c|c|c|c|c|}
\hline $\begin{array}{r}\text { Infrastructure } \\
\text { transition }\end{array}$ & $\begin{array}{r}\text { Large } \\
\text { upfront costs } \\
\text { of } \\
\text { infrastructure }\end{array}$ & $\begin{array}{l}\text { Uncertain } \\
\text { consumer } \\
\text { response }\end{array}$ & $\begin{array}{r}\text { Recognized } \\
\text { technological } \\
\text { superiority }\end{array}$ & Price & $\begin{array}{r}\text { Externalities } \\
\text { (environment, } \\
\text { diversification, } \\
\text { social, etc.) }\end{array}$ & $\begin{array}{r}\text { Requires } \\
\text { consumer } \\
\text { to have } \\
\text { new } \\
\text { appliances }\end{array}$ & $\begin{array}{r}\text { Compatibility } \\
\text { with old } \\
\text { networks }\end{array}$ & $\begin{array}{r}\text { Diffusion } \\
\text { time } \\
\text { (years) }\end{array}$ \\
\hline Electricity & -- & + & ++ & . & ++ & - & -- & 60 * \\
\hline Natural Gas & -- & . & . & ++ & + & - & ++ & 15 ** \\
\hline Hydrogen & -- & - & - & -- & ++ & - & + & \\
\hline
\end{tabular}

(++): strong advantage; (+): advantage; (.): even or not applicable; (-) disadvantage; (--) serious barrier.

* before reaching the "tipping point"; ** average number of the years before reaching $10 \%$ of the national energy mix in the

European countries surveyed in the paper.

The introduction of hydrogen needs both the availability of infrastructure and technology. As for hydrogen technologies, particularly fuel cells and onboard storage devices, they are being developed by public and private partnerships around the world. Progresses have been recently announced particularly in terms of durability and reliability of the fuel cell. However, the competitive level is still far from being reached and the research and development (R\&D) period has been taking decades without any significant entry in the market. (IEA, 2005; Lattin and Utgikar, 2007)

Introducing a radical innovation-such as hydrogen and fuel cells--in the market needs public intervention at three levels: firstly, to support the pre-market stages in order to make hydrogen technologies competitive with conventional technologies (research, development and demonstration R\&DD); secondly, to support the marketentry and infrastructure investments; and finally, to internalize the environmental and social externalities in order to level the "playing field" of the competition with traditional technologies and thus creating conditions for the market diffusion. (Bourgeois and Mima, 2003)

In the actual liberalized European framework and considering financial burdens faced by States, public and private partnership demonstration projects at the local level could accelerate the transition. 


\section{Conclusion}

Natural gas and electricity in Europe, as well as techno-economical analysis of the hydrogen infrastructure, generally converge to the vision that infrastructure starts in densely populated areas, with a huge demand potential, in a decentralized production configuration and further evolves towards a centralized production following the expansion of the demand. Even if estimated at a least-cost way, the infrastructure is projected to cost several billions of euros. This huge amount of investment and the uncertainty about the demand uptake make it unlikely that private agents deploy alone the necessary infrastructure to overcome the "chicken-or-egg" dilemma. The same problem occurred in the past when the State felt a strategic necessity to develop energy networks such as pipelines and power grids. There were also economical reasons for the State to build these networks on its own, such as scale economies, scope economies, club effects, and economic growth.

Public authorities have an important role to play during the hydrogen transition. They can improve the context for the introduction of hydrogen into the market by: supporting R\&DD; economic instruments (e.g. carbon taxe); command and control policies (e.g. efficiency requirements, renewable energy obligation); public education; and codes and standards for hydrogen technologies. Moreover, historical review of the electricity and natural gas diffusion points out the importance of public intervention in the network diffusion.

Considering (i) the likely path of the transition (starting from small local networks); (ii) the new role of the States in the economy as a regulator more than intervener; and (iii) the financial constraints of national budgets, local partnerships between public authorities and industry can be very important for the transition by reducing uncertainty and, therefore, accelerating equipment deployment (such as fuel cell cars), while at the same time helping to ramp up investments in the infrastructure.

\section{Acknowledgements}

The author would like to thank Jean-Pierre Angelier from Grenoble University for discussing this paper, the participants of the 4th European Congress on Economics and Management of Energy in Industry (27-30 ${ }^{\text {th }}$ November 2007, Oporto), and of the Workshop of the student section of the French Energy Economists Association $\left(7^{\text {th }}\right.$ November 2007, Paris) for precious comments. Extensive feedback from two anonymous referees is also gratefully acknowledged.

\section{References}

Angelier J-P. (1994), Le gaz naturel, Cyclope, Paris.

Angelier J.-P. (2007), Economie des Industries de Réseau, PUG, Collection Eco+, Grenoble.

Angelier J.-P. and Lalanne E. (1979), « L'Evolution des relations entre l'industrie électrique et les pouvoirs publics ; comparaison historique de l'Allemagne, de la 
France, de l'Italie et du Royaume-Uni », Institut Economique et Juridique de I'Energie, Grenoble, 164 p.

Arthur W. B. (1989), "Competing Technologies : Increasing Returns and Lock-in by Historical Events", The Economic Journal, 99 (1), p. 116-131.

Ballard (2007), "Ballard Reports Solid 2006 operating Achievements and Provides 2007 Performance Targets," 01/30/07, http://www.ballard.com/

Barreto, L., A. Makihira, and K. Riahi, (2003), "The hydrogen economy in the 21st century: a sustainable development scenario", International Journal of Hydrogen Energy 28 (3), 267-284.

Barro R. (1990), "Government Spending in a Simple Model of Endogenous Growth," Journal of Political Economy 98, 5, p.103-125.

Baumol W. J., Panzar J. and Willig R. (1982) « Contestable markets and the theory of industrial structure », Harcourt-Brace-Jovanovich Publishers.

Bergougnoux J. (2000), « Les Services Publics en Réseaux », Rapport au Commissariat Général du Plan, La Documentation française, Paris.

Bourgeois B. and Mima S. (2003), "Rationales for the co-operation between firms and States within an emerging radical innovation", in: "The Economic Dynamics of Fuel Cell Technologies", Avadikyan B., Cohendet P. and Héraud J.-A. (eds.), Heidelberg: Sprinter-Verlag, pp.43-79.

British Petroleum - BP (2007), Statistical Review of World Energy, June, http://www.bp.com/statisticalreview

Braeutigam R.R. (1989), « Optimal Policies for the Natural Monopolies », in R. Schmalensee et R.D. Willig, Handbook of Industrial Organization, Elsevier, pp.12891346.

Buchanan J. M. (1965), “An Economic Theory of Club”, Economica 32, p. 1-14.

Coase R.H. (1960), "The Problem of Social Cost”, Journal of law and Economics, n`3, pp. 1-44.

Curien N. (2005), Les Economies des Réseaux, Editions La Découverte, coll. « Repères » : $n^{\circ} 293$, Paris.

David P.A. (1985), "Clio and the economics of Qwerty", American Economic Review 75 (2), 332-337.

E4Tech (2005), "The Economics of a European Hydrogen Automotive Infrastructure", A study for Linde AG, Final Report, February.

Economides N. (1996), "The Economics of Networks", International Journal of Industrial Organization, vol. 14, pp 673-699.

Energy Information Administration - EIA (2006), Annual Energy Review, http://www.eia.doe.gov/emeu/aer/natgas.html (accessed in October 17)

Estrada, J., Moe, A. and Martinsen, K.D. (1995), The Development of European Gas Markets: Environmental, Economic and Political Perspectives, John Wiley.

Finon D. and Midttun A. (2004), Reshaping European Gas and Electricity Industries: Regulation, Markets and Business Strategies, Elsevier, Paris. 
High Level Group - HLG (2003), "Hydrogen Energy and Fuel Cells : A Vision for Our Future", Summary Report, Brussels, June.

International Energy Agency - IEA (2004), Hydrogen and Fuel Cells - Review of National R\&D Programs, OCDE/AIE, Paris.

IEA (2005), Prospects for Hydrogen and Fuel Cells, OCDE/IEA, Paris.

Katz M. L. and Shapiro C. (1985), "Network externalities, competition and Compatibility », American Economic Review 75 (3), 424-440.

Lanthier P. (2006), « Les autorités publiques et l'électrification, de 1870 à 1940 : Une comparaison européenne », Annales Historiques de l'Electricité, n4, pp. 125-146.

Lattin W.C. and Utgikar V.P. (2007), « Transition to hydrogen economy in the United States: A 2006 status report", International Journal of Hydrogen Energy 32, pp.32303237.

Lévêque F. (2004), Economie de la réglementation, Collection Repères $n^{\circ} 238$, Ed. La Découverte, Paris.

MacAvoy P.W. (2001), The Natural Gas Market: Sixty Years of Regulation and Deregulation, Yale University Press, New Haven and London.

Melaina M.W. (2003), "Initiating hydrogen infrastructures: preliminary analysis of a sufficient number of initial hydrogen stations in the US", International Journal of Hydrogen Economics 28 743-755.

National Research Council - NRC (2004), The Hydrogen Economy: Opportunities, Costs, Barriers, and R\&D Needs, Board on Energy and Environmental Systems, Washington DC, p. 394.

Noam E.M. (1992), "Network Tipping: The Rising and Fall of the Public Network Monopoly", in Telecommunications in Europe, Oxford University Press, Oxford, point 3, pp.26-43.

Odell P.R. (2001), Oil and Gas: Crises and Controversies 1961-2000, Multi-Science Publishing Company Ltd, Brentwood.

Ogden J. (1999a), 'Prospects for Building a Hydrogen Energy Infrastructure', Annual Review of Energy and the Environment, vol. 24, pp. 227-279.

Ogden J. (1999b), "Developing an infrastructure for hydrogen vehicles: a Southern California case study", International Journal of Hydrogen Energy 24, 709-730.

Paquier S. and Williot J-P. (2005) (sous la direction de), L'Industrie du Gaz en Europe aux XIXe et XXe Siècles : L'innovation Entre Marchés Privés et Collectivités Publiques, PIE Peter Lang, Bruxelles.

Plotkin S. (2007), "Examining Hydrogen Transitions," Energy Systems Division, Argonne National Laboratory for the U.S. Department of Energy, ANL-07/09, February.

Shapiro C. and Varian H.R. (1998), Information Rules: A Strategic Guide to the Network Economy, Harvard Business School Press, Boston.

Smit M. (2006), «Developing Gas Markets: Lessons Learned From the Netherlands », $23^{\text {rd }}$ World Gas Conference, Amsterdam.

Sperling D. and Cannon J. (2004), The Hydrogen Energy Transition, Elsevier, 266 p. 
Stiller C., Seydel P., Bünger U. and Wietshel M. (2007), «Assessment of the Regional Hydrogen Demand and Infrastructure Build-up for 10 European Countries", on behalf of the HyWays Consortium.

Stoffaës C. (1994), (dir.) Entre Monopole et Concurrence, la régulation de l'énergie en perspective historique, Éditions P.A.U., Paris, 1994, 340 p.

Teece D.J. (1990), « Structure and organization of the natural gas industry: differences between the United States and the Federal Republic of Germany and implications for the carrier status of the pipelines", Energy Journal 11 (3), pp. 1-35.

Tzimas E., Castello P. and Peteves S. (2006), "The evolution of size and cost of a hydrogen delivery infrastructure in Europe in the meium and long term", International Journal of Hydrogen Energy doi: 10.1016/j.jjhydene.2006.10.017.

Wietschel M., Hasenauer U. and de Groot A. (2006), "Development of a European hydrogen infrastructure scenarios- $\mathrm{CO} 2$ reduction potential and infrastructure investment", Energy Policy 34 pp. 1284-1298.

World Resources Institute - WRI (2006), Climate Analysis Indicators Tool (CAIT) online database version 3.0., Washington, DC: World Resources Institute, available at: http://cait.wri.org

Yang C. and Ogden J. (2005), "Analyzing natural gas based hydrogen infrastructure-optimizing transitions from distributed to centralized H2 production," Proceedings of National Hydrogen Association Conference, Washington, D.C., March 29-April 1.

Yang C. and Ogden J. (2007), "Determining the lowest-cost hydrogen delivery mode", International Journal of Hydrogen Energy 32, 268-286.

\section{Footnotes}

\footnotetext{
${ }^{\text {i }}$ Demonstration projects of hydrogen for transportation in Europe: http://www.h2moves.eu/ . Worldwide demonstration projects atlas http://www.iphe.net/newatlas/atlas.htm (300 projects surveyed).

${ }^{\text {ii }}$ Between 1938 and 1952, natural gas was discovered in the Po Valley, Italy. In 1951, the Lacq deposits were found in France, and the Slochteren in Groningen (Netherlands), in 1959. In 1965, the reservoir West Sole was discovered in the British side of the North Sea. In 1969, the reservoir Ekofisk was discovered in the Norwegian continental shelf of the North Sea.

iii Natural gas production is traditionally concentrated in the hands of a small number of exporters, for the most public companies: Algeria (Sonatrach), Norway (Statoil), Russia (Gazprom) and the Netherlands (Gasunie).
} 